\title{
The Impact of Teaching the Effects of Dextrin Binder Composition on Bamboo Fiber and Dried Clove Leaves Briquettes to High School Students
}

\author{
Asep Bayu Dani Nandiyanto*, Alya Chairunnisa Tahira, Budiman Anwar, Rina Maryanti \\ Universitas Pendidikan Indonesia, Jl. Dr. Setiabudi no 299, Bandung, 40154, Indonesia \\ nandiyanto@upi.edu, alyatahira@upi.edu,budimananwar@upi.edu, maryanti.rina@upi.edu
}

\begin{abstract}
This study aims to determine the optimum binder composition and to teach students about the making of briquettes from a mixture of bamboo fiber with dried clove leaves. The methods are carbonization at $200-220^{\circ} \mathrm{C}$ for $7-$ $20 \mathrm{~h}$, milling, sieving, stamping, and drying process with dextrin binder with concentrations of 20,40 , and $60 \%$. The bamboo fibers and dried clove leaves are set at a composition ratio of 10:1. The particle size is mixed at the size of 600$250 \mathrm{um} ; 250-89 \mathrm{um}$, and $<63 \mathrm{um}$. This research uses a learning video with an interesting subject about briquette production from bamboo fiber and dried clove leaves to analyze the effectiveness of learning video to 15 high school students, tested with 11 pre-test and post-test questions. To support the analysis, characterization of the briquettes is conducted. The experimental results show that briquettes made from bamboo fibers and dried clove leaves with a concentration of $60 \%$ have a good solidity, durability, fuel consumption, and moisture content, while the $20 \%$ have a good combustion ability. This research is important to reduce agricultural waste by recycling into briquettes for alternative fossil fuels, and the learning media through video enhances the comprehension of the subjects about biomass briquettes with dextrin binder.
\end{abstract}

Keywords: agricultural waste, briquette, dextrin binder, high school student, learning.

\section{Corresponding Author}

* Departemen Pendidikan Kimia, Universitas

Pendidikan Indonesia, Jl. Dr. Setiabudi No. 229

Bandung, Indonesia

*nandiyanto@upi.edu

\section{Introduction}

Briquette is one of the alternative coal products because coal combustion could cause pollution. In China, the combustion of coal causing sulphur emission and leads to acid rain that could spread to Japan and Korea through winds (Zhang, Sun and Xu, 2018). Briquette can be made from biomass. Biomass mostly found as a waste, which can be from agriculture, livestock, plantation, and fishery (Patabang, 2012). Bamboo biomass is utilized because it is easy to cultivate, and its productivity per unit area is higher than other plants about 33-110 tons/ha/year with a short harvest period (1-3 times/year) so the continuity is maintained (Zhang, Sun and Xu, 2018). Additionally, there are numerous distillations of clove oil in the clove-producing areas (Suarya, 2008). One of the utilizations on the clove leaves after the distillation process could be made into briquette raw material because of the large waste amount of the clove oil distillation that people seek for. The knowledge about making a briquette is important to students because students can get knowledge and comprehension from the learning process. However, this learning process needs an effective method and media. One of the learning media that could be used is video.

Learning video is one of the developments of visual media, audio, or audiovisual in this globalization era (Putra, Tastra, and Suwatra, 2014). The advantages of video media are serving realistic objects, attractive, good to achieve psychomotor learning, portable, and easy to distribute (Purwanti, 2015).

The study of bamboo fibers and dried clove leaves briquettes has been conducted by many researchers. Tambara and Serli (2019) analyzed coal briquettes and carbonized bamboo briquettes with the results of carbonized bamboo briquettes having a water content of $9.23 \%$ that is lower than the moisture content of coal briquettes. Meanwhile, the ash content of carbonized bamboo briquettes is quite high at $14.5 \%$ and the fly substance content is $8.44 \%$ (Tambaria and Serli, 2019). Kale, Mula, Iskandar, and Abrina (2019) made briquettes with bamboo fibers with cow dung binder, the briquette has a more stable burning rate and lower moisture content in $0.197 \%$ (Kale, Mula, Iskandar, and Abrina, 2019). Briquettes that are made from bamboo fiber studied by Brunerová Roubík, and Brožek (2018) showed that the ash content is $1.16 \%$ and the mechanical durability is $97.80 \%$ which is good for briquettes (Brunerova, Roubik, and Brozek, 2018).

Furthermore, Aklis (2018) made dried clove leaves briquettes from the leftover essential oil distillation and wood charcoal. The result for the highest burning rate is in 
the composition ratio of 60:40 on wood charcoal and dried clove leaves (Aklis, 2018). Corresponding to this research, Yulinar (2020) has a result of higher moisture content, volatile matter, and calories in the composition ratio of 20:40 on dried clove leaves and wood charcoal (Yulinar, 2020).

Additionally, there is some research about the learning process with video. Pamungkas, Ihsanudin, Novaliyosi, and Yandari (2018) researched the impact of learning videos about mathematics history on college students. The result is learning videos categorized as good and feasible to use for learning media (Pamungkas, Ihsanudin, Novaliyosi, and Yandari, 2018). Hamdanillah, Harjono, and Susilawati (2017) analyzed the effect of learning video for physics to students. The result shows the learning video enhances the students' knowledge especially in a few theories (Hamdanillah, Harjono, and Susilawati, 2017). Sulistya (2017) investigated the impact of learning video with earth surface and weather topic for elementary school students, which results in a very feasible learning video to use in the field (Sulistya, 2017). Imamah (2012) made an animation video of plant life systems topic with the subject of junior high school students.

The animation video manages to improve the score of the students' report on the science program (Imamah, 2012). Research with high school students' subjects observed by Pradilasari, Gani, and Khaldun (2019) who analyze the effect of audiovisual with the colloid topic. The result showed that audiovisual learning media is very feasible to use as teaching material with an average feasible score of $86.63 \% \%$ (Pradilasari, Gani, and Khaldun, 2019). However, no research has discussed instructional videos on briquettes of bamboo fibers mixed with dried clove leaves for high school students. Therefore, this paper is made to analyze these two parameters. Discussing the problem of biomass briquettes as an alternative fuel is very important for students to learn.

Therefore, this study aims to determine the best binder composition and to teach high school students through an experiment video about the making of briquettes from biomass mixture of bamboo fiber with dried clove leaves. Researchers use the carbonization method at a temperature of $200-220^{\circ} \mathrm{C}$ for $7-20 \mathrm{~h}$ depending on the mass of bamboo and dry clove leaves inside the oven, milling, sieving to uniform the particle size (Oladeji, 2010), stamping, and drying to made briquettes with dextrin binder with a composition variation of 20,40 , and $60 \%$. The biomass composition ratio for bamboo fibers and dried clove leaves are 10:1. The dried clove leaves have the lower composition because the dried clove leaves contain essential oil in the number of 1-4\% (Nurhadianty, Cahyani, Nirwana, Dewi, Abdilah, and Pratama, 2017), has 9.925\% ash content (Aklis, 2008) which is higher than ash content on bamboo fibers in the number of $2.70 \%$. The ash content is one of the parameters to make briquette according to the standard SNI 01-6235-2000, where the ash content is a maximum of $8 \%$ (Putra, Mokodompit, and Kuntari, 2016).

Characterization of briquettes is obtained by testing the durability, moisture content, density, burning rate, specific fuel consumption (SFC), water boiling test, and percentage of water resistance index. Also, a learning video about briquettes is made to analyze the effectiveness of learning media for 15 high school students who are tested through 11 pretest and posttest questions. Systematics that are carried out starts from assessing students' abilities (pretest), delivering teaching on briquette making supported by theoretical explanations through learning media in the form of videos, and reassessing student abilities (posttest).

The analysis is supported by direct evaluation (through assessment). This research teaches a new way of learning to high school students. Besides their usual topic about school subjects, this research creates a video about the experiment to introduce students to an alternative fuel which shows that briquettes could be made from biomass such as bamboo fiber and dried clove leaves with variations of the dextrin binder composition. It is expected that the briquettes could be used as an alternative to fossil fuel. The experimental result shows that briquettes made from bamboo fibers and dried clove leaves at a concentration of $60 \%$ have a good solidity, durability, and moisture content, while the concentration of $20 \%$ has a good combustion ability. Also, the learning media through video enhances the comprehension of high school students about biomass briquettes. Therefore, this research is important in attempts to reduce agricultural waste by recycling into briquettes for alternative fossil fuels.

\section{Theoretical Framework}

Table 1 shows the comparison of the briquettes from previous research and this research. Briquettes are a powderforming substance made of a larger material with clumping prose compacted with pressure and the raw material used with or without a drying process where the heat value and density are high which save storage space, and also the combustion is equivalent to coal. The requirements for good briquettes are not smoky and the gas emission is not harmful. As a result, briquettes are one of the appropriate innovations for replacing coal because they emit such minimal pollutant (Aisyah, Saifullah, and Satya, 2017).

Table 1. Comparison of the Briquettes Research

\begin{tabular}{|c|c|c|c|}
\hline References & Material & $\begin{array}{l}\text { Result of the } \\
\text { Research }\end{array}$ & $\begin{array}{l}\text { The result of } \\
\text { this Research }\end{array}$ \\
\hline $\begin{array}{c}\text { (Brunerova, } \\
\text { Roubik, and } \\
\text { Brozek, 2018) }\end{array}$ & $\begin{array}{l}\text { Bamboo } \\
\text { Fiber }\end{array}$ & $\begin{array}{l}\text { Mechanical } \\
\text { Durability: } \\
97.80 \%\end{array}$ & $\begin{array}{l}66.56 \%(60 \% \\
\text { dextrin) }\end{array}$ \\
\hline (Aklis, 2008) & $\begin{array}{c}20 \% \text { dried } \\
\text { clove leaves } \\
+80 \% \text { wood } \\
\text { charcoal }\end{array}$ & $\begin{array}{l}\text { Burning rate: } \\
0.27 \mathrm{~g} / \mathrm{min} \text { on } \\
\text { the fourth } \\
\text { minutes }\end{array}$ & $\begin{array}{l}\text { Burning rate: } \\
1.15 \mathrm{~g} / \mathrm{min} \text { on } \\
\text { the third } \\
\text { minutes }(20 \% \\
\text { Dextrin) }\end{array}$ \\
\hline $\begin{array}{c}\text { (Iskandar and } \\
\text { Surtanti, 2016) }\end{array}$ & Bamboo & $\begin{array}{l}\text { Moisture } \\
\text { Content: } 5.21 \% \\
\text { in } 100 \mathrm{~g} \\
\text { Briquette }\end{array}$ & $\begin{array}{l}\text { Moisture } \\
\text { Content: } \\
30.97 \%(60 \% \\
\text { dextrin binder) } \\
\end{array}$ \\
\hline $\begin{array}{c}\text { (Putra, } \\
\text { Mokodompit, } \\
\text { and Kuntari, } \\
\text { 2016) }\end{array}$ & Bamboo & $\begin{array}{l}\text { Moisture } \\
\text { Content: } \\
12.06 \%\end{array}$ & $\begin{array}{l}\text { Moisture } \\
\text { Content: } \\
30.97 \%(60 \% \\
\text { dextrin binder) }\end{array}$ \\
\hline
\end{tabular}

One of the best briquettes is briquette produced from biomass. Biomass is an organic material or residual material 
after the plant or organic material is dried. Biomass, which is good for briquettes, must have a low water content of approximately $10-15 \%$ because it can cause problems during grinding and will take a significant amount of energy to dry. In addition, small particle size is also needed so that it can be stored in a shelter or storage space. Finally, the ash content in biomass has to be generally low. However, the ash in biomass contains minerals such as potassium which are volatile cause a low combustion temperature. Bamboo has an $8 \%$ ash content that is still incredibly low and ideal for producing briquettes (Grover and Mishra, 1996).

Therefore, it is important to add other media when improving the understanding of the production of the briquettes (Maryanti, Hufad, Sunardi, Nandiyanto, and AlObaidi, 2020) and one of which is audiovisual media. Audiovisual media is a set of tools that can project moving and sound images. The combination of images and sounds forms the same character as the original object. The tools included in the audio-visual media category is television, video-VCD, sound, slides, and films (Sanaky, 2013).

\section{Methods}

The methods in this study include the making of the bamboo fiber and drying the clove leaves briquette, giving pretest and posttest towards the students.

\subsection{Making Bamboo Fiber and Dry Clove Leaf Briquettes}

As for the experimental process, several tools are used such as an oven, a mesh sieve, a thermometer, a digital scale, and a beaker. Bamboo fibers are obtained from the waste of kite-making in Bandung City. Dried clove leaves are obtained from clove gardens in the Awiligar area, Bandung, where many clove plantations can be found. Dextrin is used as a binder with a total of 30 grams and is mixed with water.

Figure 1 shows the steps in the making of briquettes from a mixture of bamboo fibers and dried clove leaves. The bamboo fibers waste and dried cloves leaves are dried naturally because the color has changed from green to brown. Therefore, the leaves and bamboo are directly heated in an oven at $200-220^{\circ} \mathrm{C}$ for seven hours until the leaves and bamboo turned black. The bamboo and clove leaves that have been blackened through the carbonization process are easier to destroy so we only use a wood stick to grind and get the bamboo and clove leaves powder. The bamboo and clove leaves powder obtained are not uniform in size. So, a mesh sieve is used to filter the bamboo and clove leaves powder.

The sizes of bamboo powder and clove leaves used are $0.60-0.250 \mathrm{~mm}$; $0.250-0.089 \mathrm{~mm}$; and $>0.063 \mathrm{~mm}$ with the composition of bamboo powder and clove leaves used are $1: 2: 3$ at sizes $<0.063 \mathrm{~mm} ; 0.60-0.250 \mathrm{~mm}$; and $0.250-0.089$ $\mathrm{mm}$, respectively. While the ratio of bamboo powder and clove leaves used is 10:1. The binder used is dextrin with composition variations of 20,40 , and $60 \%$ by weight of briquettes with $15 \mathrm{~mL}$ of water to produce 12 briquettes for each binder composition. All materials are mixed and molded in a tube-shaped with a diameter of $3 \mathrm{~cm}$ and pressed using digital weight scales to determine the resulting pressure. In this briquette molding process, a pressure of $18.4-20 \mathrm{~kg}$ is used for 1-minute compaction time. The briquettes are dried in an oven with a temperature of $30-60^{\circ} \mathrm{C}$ for three hours and then at room temperature for 12 hours until a constant weight obtained. This indicates that all the water contained has evaporated and the binder has reacted with all the materials.

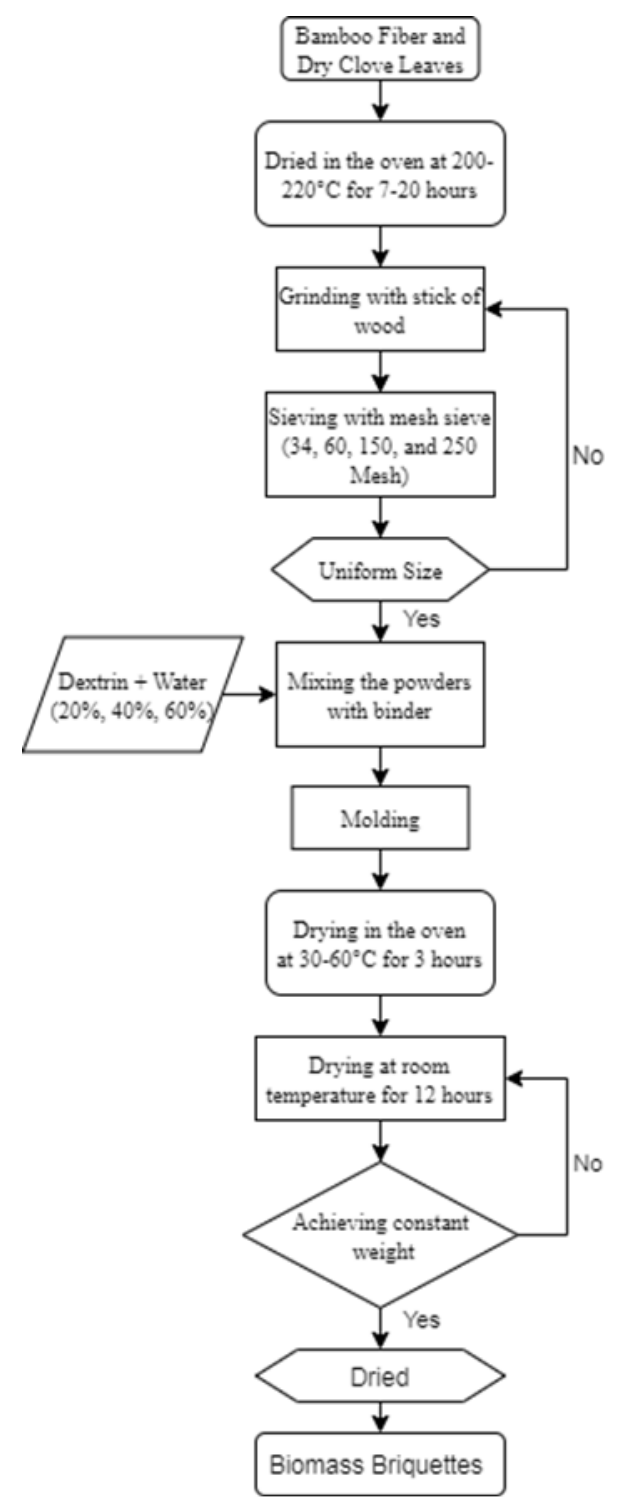

Fig. 1 The flowchart of the making of briquettes from bamboo fiber and dried clove leaves.

\subsection{Pretest and Posttest Implementation}

The subjects of this study are 15 high school students on the island of Java, Indonesia. The trial conducted in three stages; each stage is evaluated using the direct observation method (through assessment).

Table 2 shows the pretest and posttest questions given to students. The first step is a pretest that consists of 11 questions about biomass briquettes from bamboo fibers and clove leaves. The second step is encouraging students to watch learning video about biomass briquettes contains theory, the method to made briquettes, and the briquette's 
quality test. The third step is giving the posttest questions where the questions are the same as the pretest questions to determine the increase in students' insight after a learning video is given.

Table 2. Pretest and posttest questions are given to students.

\begin{tabular}{|l|l|}
\hline No & \multicolumn{1}{|c|}{ Questions } \\
\hline 1. & Coal briquettes are one of the uses of the biofuel. \\
\hline 2. & Biobriquettes are briquettes made from biomass. \\
\hline 3. & Good briquettes are those that have the highest ash content. \\
\hline 4. & Briquettes can be used repeatedly as fuel. \\
\hline 5. & $\begin{array}{l}\text { Briquettes are made by mixing carbon with a binder. The } \\
\text { purpose of the binder on the briquette is to attract water and } \\
\text { form a solid texture by binding the two substrates. }\end{array}$ \\
\hline 6. & $\begin{array}{l}\text { The carbon raw material for briquettes is obtained from the } \\
\text { carbonization process of agro-industrial waste. Then, } \\
\text { briquettes are made by mixing carbonized raw materials with } \\
\text { binder materials. Carbonization is the process of converting } \\
\text { organic material into charcoal. }\end{array}$ \\
\hline 7. & $\begin{array}{l}\text { Briquettes are made by mixing carbonated raw materials with } \\
\text { binder ingredients. Bamboo fiber is a type of biomass that can } \\
\text { be used as raw material for briquettes. }\end{array}$ \\
\hline 8. & $\begin{array}{l}\text { Briquettes are made by mixing carbonized raw materials with } \\
\text { binder ingredients. The lower the cellulose content in bamboo } \\
\text { fibers as a carbon raw material, the better the briquette } \\
\text { quality. }\end{array}$ \\
\hline 9. & $\begin{array}{l}\text { The carbon raw material for briquettes is obtained from the } \\
\text { carbonation process from agro-industrial waste. Then, } \\
\text { briquettes are made by mixing raw materials that have been } \\
\text { carbonated with a binder. If we use bamboo fibers and dry } \\
\text { clove leaves, the raw material does not have to be ground first } \\
\text { because the particle size does not affect the quality of the } \\
\text { briquettes. }\end{array}$ \\
\hline 10. & $\begin{array}{l}\text { One of the goals of carbonation of bamboo fibers and dried } \\
\text { clove leaves is to reduce moisture content. }\end{array}$ \\
\hline 11. & $\begin{array}{l}\text { One of the parameters in briquettes is the specific fuel } \\
\text { consumption (SFC), where SFC is the amount of briquette } \\
\text { used to produce energy. The higher the SFC, the better the } \\
\text { quality of the briquette (more economical). }\end{array}$ \\
\hline
\end{tabular}

Basic student's information including IQ score and the average score of Chemistry, Physics, and Biology subjects are obtained before starting the demonstration to support the research instrument. The technique of IQ scoring carried out through an IQ test on the official website (tes-iq.com). Students are encouraged to answer questions given, while the technique of scoring the Chemistry, Physics, and Biology subject is carried out by adding and dividing the report scores (average) of each student.

\section{Results and Discussion}

The results and discussion section includes the characterization of briquettes according to the parameters used and the qualitative analysis of students' teaching test results. The physical appearance of the briquette shows black color with a diameter of $2.8 \mathrm{~cm}$ and the height are varied from 0.7 to $1 \mathrm{~cm}$ after the briquette's drying process. After combustion, the $20 \%$ composition have live coal for about 30 minutes after the fire goes out. Meanwhile, for the $40 \%$ and $60 \%$ dextrin composition no sign of live coals after the fire goes out.

\subsection{Briquette Characterization}

The results of the briquette quality test analysis consist of compressed density, relaxed density, relaxation ratio, durability, water-resistant index, moisture content, burning rate, specific fuel consumption (SFC), and water boiling test.

Figure 2 describes the compressed density of bamboo powder briquettes and dry clove leaves in the three variations of the binder composition. Compressed density is tested by weighing and measuring the dimensions (height, diameter) of the briquettes after printing. From Figure 2, we can find that the average compressed density for the $20 \%$ binder composition is $0.7373 \mathrm{~g} / \mathrm{cm}^{3}$, the $40 \%$ binder composition is $0.8511 \mathrm{~g} / \mathrm{cm}^{3}$, and $60 \%$ is $1.0618 \mathrm{~g} / \mathrm{cm}^{3}$. Of the three compositions, the $60 \%$ dextrin binder is the largest as the curve increases as the dextrin binder composition also increases. The findings of the $60 \%$ binder composition have the best-compressed density occurs because the binder attracts water and form a solid texture by binding the two substrates. The result is better than the research conducted by Tumuluru, Tabil, Song, Iroba, Meda (2015) that has the briquette's compressed density at $0.595 \mathrm{~g} / \mathrm{cm}^{3}$. The larger the compressed density, the better the density of the briquettes, especially when pressed (Tumuluru, Tabil, Song, Iroba, and Meda, 2015).

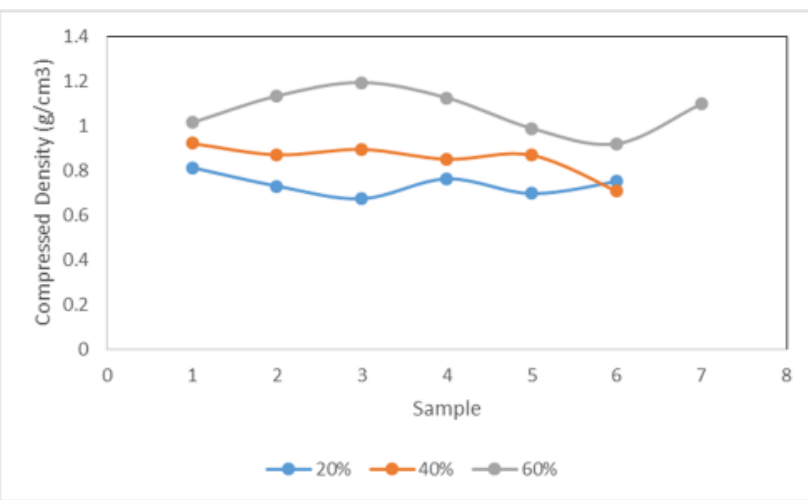

Fig.2 Compressed Density with variations of 20,40 , and $60 \%$ dextrin.

Figure 3 illustrates the relaxed density briquette bamboo powder and dry clove leaves against the three variations of the binder composition. Bamboo powder and cloves leaves. From Figure 3, it can be seen that the three compositions found where the average relaxed density is at the $20 \%$, the binder composition is $0.4813 \mathrm{~g} / \mathrm{cm}^{3}$, closer to the $40 \%$ binder composition of $0.5399 \mathrm{~g} / \mathrm{cm}^{3}$. While the dextrin binder with a composition of $60 \%$ has the highest average of 0.6806 $\mathrm{g} / \mathrm{cm}^{3}$. Of the three compositions, the $60 \%$ dextrin binder is the largest, and the curve increases as the dextrin binder composition also increase. The findings of the $60 \%$ binder composition have the best-relaxed density occurs because of the binder attract water and form a solid texture by binding the two substrates. The result is better than the research conducted by Mitchual, Frimpong-mensah and Darkwa 
(2013) that has a briquette from species $C$. pentandra with relaxed density at $0.409 \mathrm{~g} / \mathrm{cm}^{3}$ where the briquettes are weighed and measured in volume after removed from the mold and a constant weight is obtained as a sign that the briquettes are completely dry (Mitchual, Frimpong-mensah, and Darkwa, 2013).

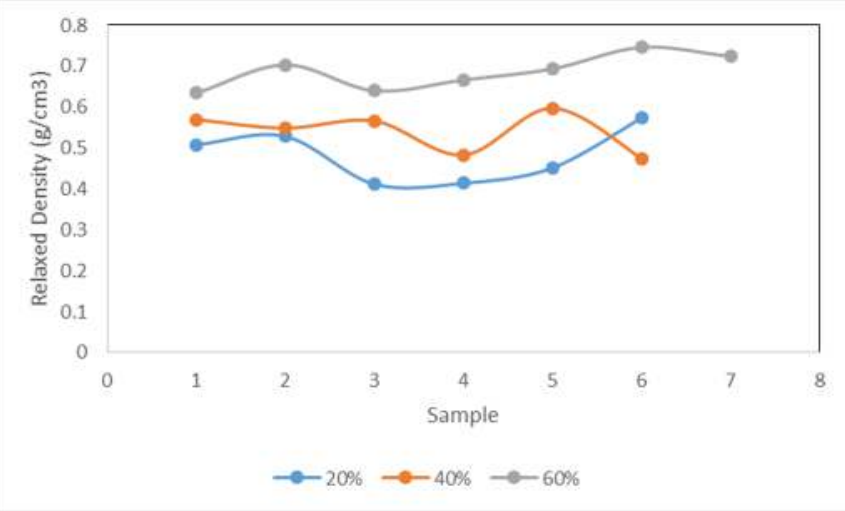

Fig. 3 Relaxed Density with variations in the binder composition of 20 , 40 , and $60 \%$ dextrin.

Figure 4 is the relaxation ratio of bamboo powder briquettes and dry clove leaves in the three variations of the binder composition. Relaxation Ratio is the density of briquettes when the briquettes are stable. From Figure 4, we can see that the average value of the relaxation ratio of the three compositions is almost close, namely 1.5507 for $20 \%$ of the binder composition, 1.5796 for $40 \%$ of the binder composition, and 1.5694 for $60 \%$ of the binder composition. This result shows that $20 \%$ of dextrin composition has the best stability because it has a small shrinkage. The result is less than the research conducted by Oladeji (2010) showing a briquette from corncob with a relaxation ratio of 1.70 . This is conducted by calculating the ratio of briquettes before drying and after drying by comparing the values of compressed and relaxed density (Oladeji, 2010).

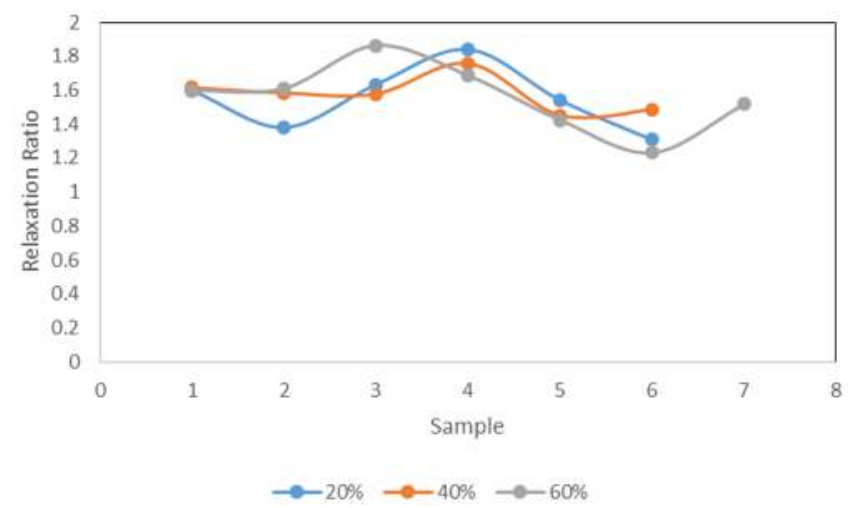

Fig. 4 Relaxation Ratio with variations in the binder composition of 20,40 , and $60 \%$ dextrin.

Figure 5 shows the values of percentage of durability index for briquettes of bamboo powder and dry clove leaves for the three variations of the binder composition. The durability test is carried out by dropping the briquettes that have been inserted into the airtight plastic above $2.90 \mathrm{~m}$ for three times of impact in each sample. Then the mass of the initial briquette is reduced by the mass of the briquette that is still intact after the impact without counting the powder that has been hit. From Figure 5, it can be seen that the three binder compositions, the average PDI for $20 \%$ of dextrin binder is the easiest to break because it is the smallest in $48.7091 \%$. For $40 \%$ dextrin binder is $56.1099 \%$, and the biggest and the strongest is in the dextrin binder composition of $60 \%$ with an average PDI of $66.5612 \%$. The curve increases as the binder composition also increase. The findings of the $60 \%$ binder composition have the best durability index because the binder attracts water and forms a solid texture by binding the two substrates. Therefore, the higher the binder composition, the better the durability. The result is less than the research conducted by Widodo (2016) that has a briquette with the percentage of weight loss for only $0.61 \%$. This durability test is used to determine how strong or resistant briquettes of bamboo fibers and dry clove leaves are against impact (Widodo, 2016) and to measure the impact force during storage or transportation (Tumuluru, Tabil, Song, Iroba, and Meda, 2015).

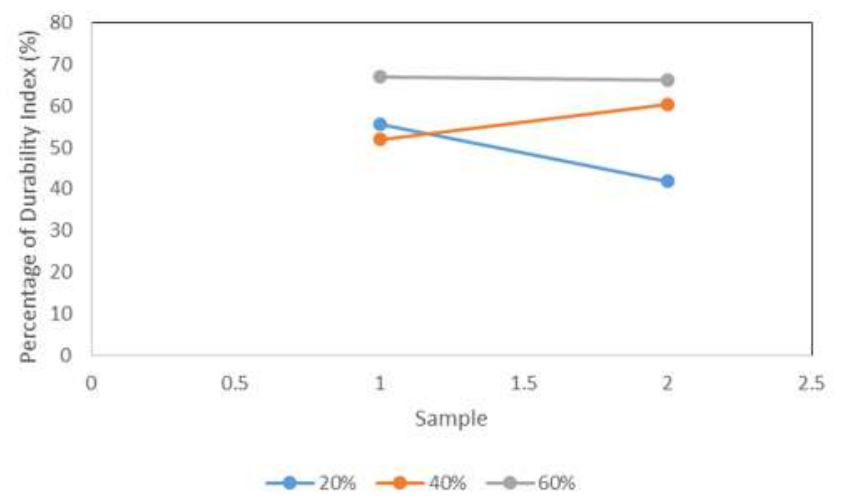

Fig. 5 Percentage of Durability Index (PDI) with variations in the binder composition of $20 \%, 40 \%$, and $60 \%$ dextrin.

Figure 6 shows the percentage of moisture content of bamboo powder briquettes and dry clove leaves in the three variations of the binder composition. The moisture content is essential to calculate because it affects the quality of the briquettes. From Figure 6 it can be concluded that the three variations of the binder composition of bamboo briquettes and clove leaves have the average moisture content with binder composition of $20 \%$ is close to $40 \%$, in the number of $36.1810 \%$, and $37.3810 \%$, respectively. The lowest water content is obtained by bamboo briquettes and clove leaves at $60 \%$ and the binder composition with a value of $30.9723 \%$. Among three compositions, the $60 \%$ dextrin binder is the lowest and the curve decreases as the dextrin binder composition increases. The findings of the $20 \%$ binder composition have the lowest moisture content because the binder attracts water so the briquettes in this composition have the lowest rate to attract water. The result is better than the research conducted by Singh (2004) that has a biomass briquette with a percentage moisture content of $40-85 \%$. Biomass is naturally hygroscopic so it can absorb and remove water from its atmosphere. However, if the water content is high, it causes swelling and destruction of the 
briquettes. It also affects the thermochemical conversion process, namely combustion (Singh, 2004).

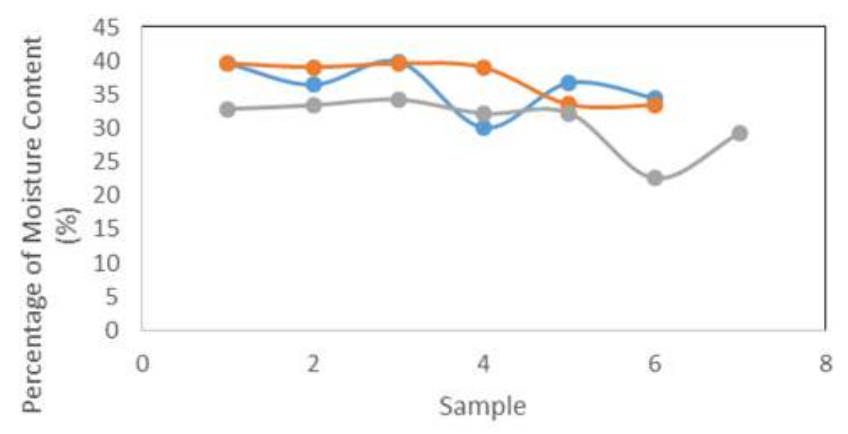

\footnotetext{
$-20 \% \rightarrow-40 \% \rightarrow 60 \%$

Fig. 6 Percentage of Moisture Content with variations in the composition of $20 \%, 40 \%$, and $60 \%$ dextrin binders.
}

Figure 7 displays the curves of the Percentage of Water Resistance Index for briquettes of bamboo powder and dry clove leaves in the three variations of the binder composition. The briquettes are soaked in water for two minutes until they disintegrated in water. From Figure 7, it can be observed that from the three variations in composition, bamboo briquettes and clove leaves with a composition of $20 \%$ and $40 \%$ have the highest PWRI values, namely 98.4913, and 92.4237\%, respectively. Meanwhile, bamboo briquettes and clove leaves with $60 \%$ binder variation have the lowest PWRI value, namely $47.4324 \%$. The curve decreases as the dextrin binder composition increases. The result is less than the research conducted by Yaman, Şahan, Haykiri-Açma, Şeşen, and Küçükbayrak (2001) that has a briquette from cotton refuse with the time of water resistance measured in 120 minutes. This test is carried out to determine how much the briquettes absorb water, which is done by immersing the briquettes in water and then measuring the time when the water is absorbed. The lower the water absorbed by the briquettes means that the briquettes are denser and less hollow, so the quality is better (Yaman, Şahan, HaykiriAçma, Şeşen, and Küçükbayrak, 2001).

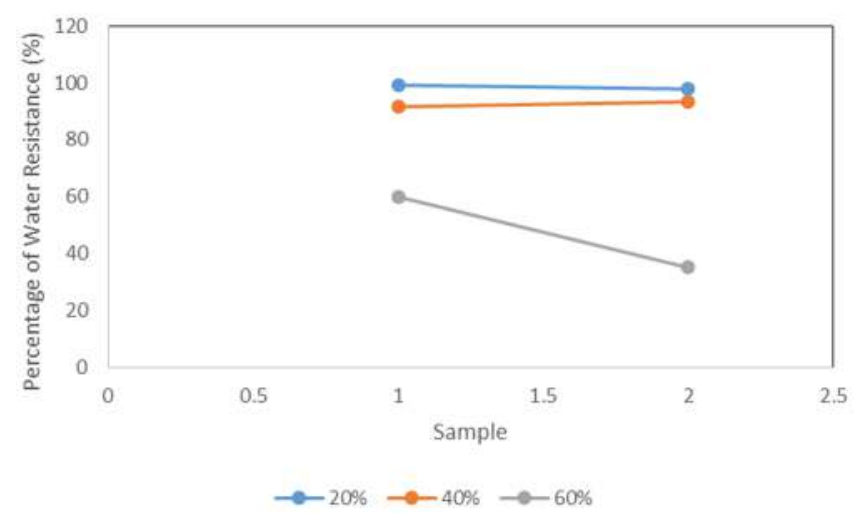

Fig. 7 Percentage of Water Resistance Index with variations in the composition of binders $20 \%, 40 \%$, and $60 \%$ dextrin.

Table 3 shows a sample table of bamboo powder briquettes and dried clove leaves with a binder composition of 20,40 , and $60 \%$ in the boiling water test. This test is a standard procedure that measures the fuel consumed within the time it takes to determine the increase in water temperature that can be raised by briquette (Kuti, 2009). From Table 3, it can be seen that the briquettes and clove leaves in the composition of bamboo briquettes and dried clove leaves with $20 \%$ binder can increase the water temperature by $15^{\circ} \mathrm{C}$ in 2 minutes 42 seconds. At $40 \%$ binder composition, bamboo briquettes and clove leaves can increase the water temperature by $15^{\circ} \mathrm{C}$ in 2 minutes 53 seconds. As for the $60 \%$ binder composition, bamboo briquettes and clove leaves can increase the water temperature by $14.5^{\circ} \mathrm{C}$ in 3 minutes 7 seconds. So, the lowest binder composition, which is $20 \%$, is the most effective at raising the water temperature because this composition could increase the water temperature in a shorter time and higher temperature rise than the other composition. The result is less than the research conducted by Yahaya and Ibrahim (2012) that has a briquette from rice husk-gum Arabic with the time of boiling duration measured in 15 minutes and the highest temperature is $100^{\circ} \mathrm{C}$ (Yahaya and Ibrahim, 2012).

Table 3. Water Boiling Test for variations

\begin{tabular}{|l|c|c|c|c|}
\hline \multirow{2}{*}{$\begin{array}{c}\text { Sample } \\
\text { Composition }\end{array}$} & \multicolumn{2}{|c|}{$\begin{array}{c}\text { Boiling } \\
\text { Duration(min) }\end{array}$} & \multicolumn{2}{c|}{$\begin{array}{c}\text { Highest } \\
\text { Temperature }\left({ }^{\circ} \mathbf{C}\right)\end{array}$} \\
\cline { 2 - 5 } & $\mathbf{1}$ & $\mathbf{2}$ & $\mathbf{1}$ & $\mathbf{2}$ \\
\hline $20 \%$ & 2.38 & 2.52 & 38 & 49 \\
\hline $40 \%$ & 2.52 & 2.54 & 45 & 43 \\
\hline $60 \%$ & 3.00 & 3.15 & 41 & 42 \\
\hline
\end{tabular}

Figure 8 displays the burning rate of briquette bamboo powder and dry clove leaves in the three variations of the binder composition. From Figure 8, it can be seen that at $40 \%$ and $60 \%$ binder composition, the average burning rate is low and the two compositions are close at $0.3676 \mathrm{gr} / \mathrm{min}$ for $40 \%$ binder composition and $0.2664 \mathrm{~g} / \mathrm{min}$ for $60 \%$ binder composition. The highest average burning rate value is found in the $20 \%$ binder composition in $1.1565 \mathrm{~g} / \mathrm{min}$ so this binder composition has the highest mass loss in the combustion. The findings of the $20 \%$ binder composition have the highest burning rate because the density in this composition is the lowest. The result is less than the research conducted by Thabuot, Pagketanang, Panyacharoen, Mongkut, and Wongwicha (2015) that has a briquette from rubberwood residue-palm fiber with the burning rate measured is $4 \mathrm{~g} / \mathrm{min}$. The burning rate test is the average mass of briquettes that burns out, by calculating the mass of briquettes before burning with the mass of briquettes after burning. Decent briquettes do not lose much mass after burning (Thabuot, Pagketanang, Panyacharoen, Mondkut, and Wongwicha, 2015). 


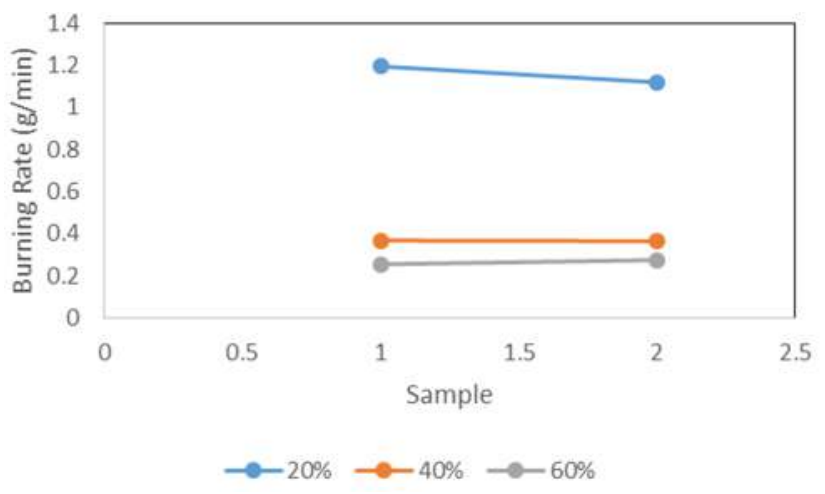

Fig. 8 Burning rate with variations in the binder composition of $20 \%$, $40 \%$, and $60 \%$ dextrin.

Figure 9 shows the specific fuel consumption of bamboo powder briquettes and dry clove leaves in the three variations of the binder composition. In testing the specific fuel consumption, $100 \mathrm{~mL}$ of water is used. From Figure 9, it can be seen that the mean SFC values for the binder's composition at $40 \%$ and $60 \%$ are close in 0.0093 and 0.0082 $\mathrm{g} / \mathrm{mL}$, respectively. While the $20 \%$ binder composition has the highest average SFC value, namely $0.02795 \mathrm{~g} / \mathrm{mL}$. Of the three compositions, the $20 \%$ dextrin binder is the largest and the curve increases as the dextrin binder composition decreases. The findings of the $20 \%$ binder composition have the largest specific fuel consumption shows that the quantity and mass of fuel required are higher to achieve the boiling task (Kuti and Adegoke, 2008) so it is not efficient. The result is less than the research conducted by Onuegbu and Ekpunobi (2015) that has a briquette from spear grass with the specific fuel consumption measured is $0.45 \mathrm{~g} / \mathrm{min}$. The specific fuel consumption test is used to determine the quantity of fuel needed to boil $1 \mathrm{~L}$ of water (Onuegbu and Ekpunobi, 2011).

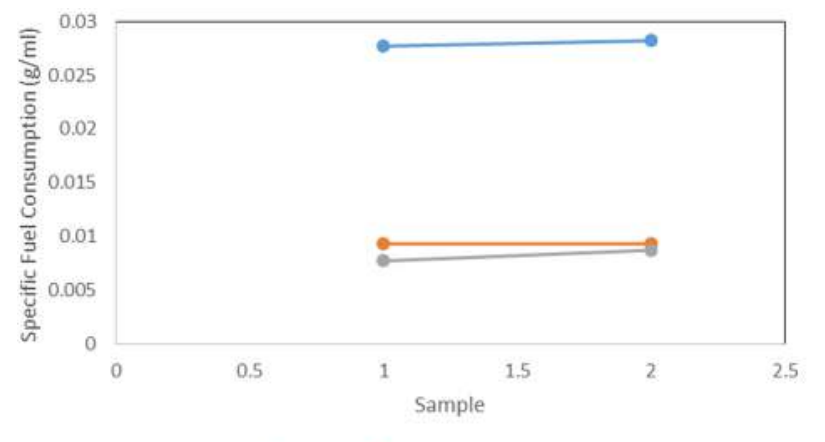

$-6-20 \% \rightarrow-40 \%-60 \%$

Fig. 9 the Specific Fuel Consumption with variations in the binder composition of $20 \%, 40 \%$, and $60 \%$ dextrin.

\subsection{Student Qualitative Analysis}

Figure 10 illustrates a diagram of the IQ test results for 15 high school students in Java, Indonesia. The chart shows the IQ scores of the students are at the normal intelligence level and five students have an IQ between 86-90, and the highest IQ score is obtained by 3 students between $96-106$
IQ score, shows that the students can learn normally without any additional support (such as subtitles or sign language).

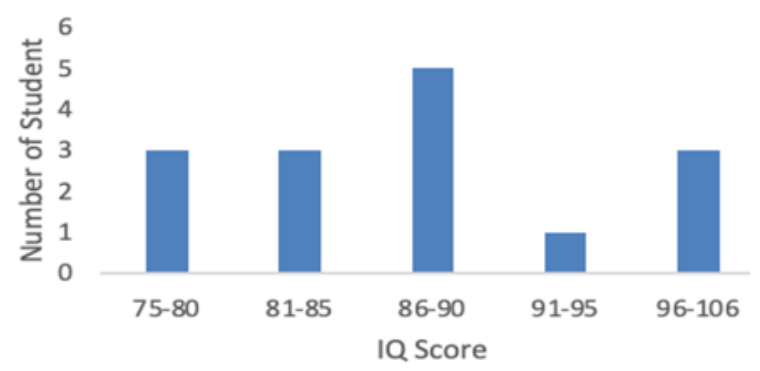

Fig.10 IQ test results for high school students

Figure 11 shows a diagram of the results of the student's average report card scores in Physics, Chemistry, and Biology subjects. The students' scores are generally in the range of $86-90$ shows that the students have an understanding of Physics, Chemistry, and Biology subjects as the foundation of this new knowledge specifically on the making of biomass briquette experiment.

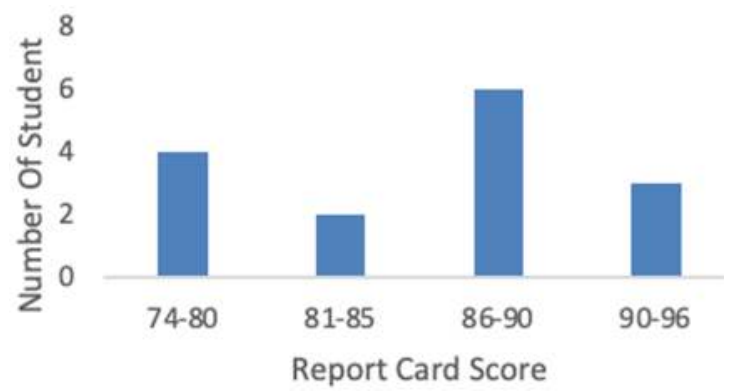

Fig. 11 Results of the Average Report Card Score of High School Students

Table 4 is the result of the comparison of the correct answers given by students from the 11 questions in the pretest and posttest stages. It can be seen that the instructional videos affect students' insights and knowledge of biomass briquettes.

Figure 12 shows the score chart of each question to analyze the effect of the pretest and posttest. It can be analyzed that the score of each question increases as the posttest is conducted.

From Table 4 and Figure 12, we can find that the pretest results show that the students do not understand several topics about biomass briquettes even though in some general questions they answer the question correctly. In general, there is an increase in the score at the posttest stage after the students watch a video about biomass briquettes. The highest score of acquisition in the number of 66.66 and the increased chart in the questions number 9 and 11, on the topics about particle size of the briquettes and specific fuel consumption, which means the students have understood these two topics after they watch the video. Also, on questions about the effect of binder material and the effect of raw material on the quality of biomass briquettes topics. There is a decrease in the posttest score shows by the number of acquisition -6.67 and for questions 3 and 6 , which means the learning video is incomplete. 
Table 4. Comparison of the students' score (\%)

\begin{tabular}{|c|c|c|c|c|}
\hline \multirow{2}{*}{ No } & \multirow{2}{*}{ Questions } & \multicolumn{3}{|c|}{ Score (\%) } \\
\hline & & Pretest & Posttest & Acquisition \\
\hline 1. & Coal briquettes are one of the uses of biofuels & 53.30 & 60.00 & 6.67 \\
\hline 2. & Bio briquettes are briquettes made from biomass & 46.67 & 86.67 & 40.00 \\
\hline 3. & Good briquettes are those that have the highest ash content & 100.00 & 93.33 & -6.67 \\
\hline 4. & Briquettes can be used repeatedly as fuel & 86.67 & 93.33 & 6.66 \\
\hline 5. & $\begin{array}{l}\text { Briquettes are made by mixing carbon with a binder. The purpose of the } \\
\text { binder on the briquette is to attract water and form a solid texture by binding } \\
\text { the two substrates }\end{array}$ & 80.00 & 100.00 & 20.00 \\
\hline 6. & $\begin{array}{l}\text { The carbon raw material for briquettes is obtained from the carbonization } \\
\text { process of agro-industrial waste. Then, briquettes are made by mixing } \\
\text { carbonized raw materials with binder materials. Carbonization is the } \\
\text { process of converting organic material into charcoal }\end{array}$ & 66.67 & 60.00 & -6.67 \\
\hline 7. & $\begin{array}{l}\text { Briquettes are made by mixing carbonated raw materials with binder } \\
\text { ingredients. Bamboo fiber is a type of biomass that can be used as raw } \\
\text { material for briquettes }\end{array}$ & 46.67 & 80.00 & 33.33 \\
\hline 8. & $\begin{array}{l}\text { Briquettes are made by mixing carbonized raw materials with binder } \\
\text { ingredients. The lower the cellulose content in bamboo fibers as a carbon } \\
\text { raw material, the better the briquette quality }\end{array}$ & 86.67 & 100.00 & 13.33 \\
\hline 9. & $\begin{array}{l}\text { The carbon raw material for briquettes is obtained from the carbonation } \\
\text { process from agro-industrial waste. Then, briquettes are made by mixing } \\
\text { raw materials that have been carbonated with the binder. If we use bamboo } \\
\text { fibers and dry clove leaves, the raw material does not have to be ground } \\
\text { first because the particle size does not affect the quality of the briquettes. }\end{array}$ & 6.67 & 73.33 & 66.66 \\
\hline 10. & $\begin{array}{l}\text { One of the goals of carbonation of bamboo fibers and dried clove leaves is } \\
\text { to reduce the moisture content }\end{array}$ & 86.67 & 100 & 13.33 \\
\hline 11. & $\begin{array}{l}\text { One of the parameters in briquettes is the specific fuel consumption } \\
\text { (SFC), where SFC is the amount of briquette used to produce energy. The } \\
\text { higher the SFC, the better the quality of the briquette (more economical) }\end{array}$ & 6.67 & $73.33^{\prime}$ & 66.66 \\
\hline
\end{tabular}

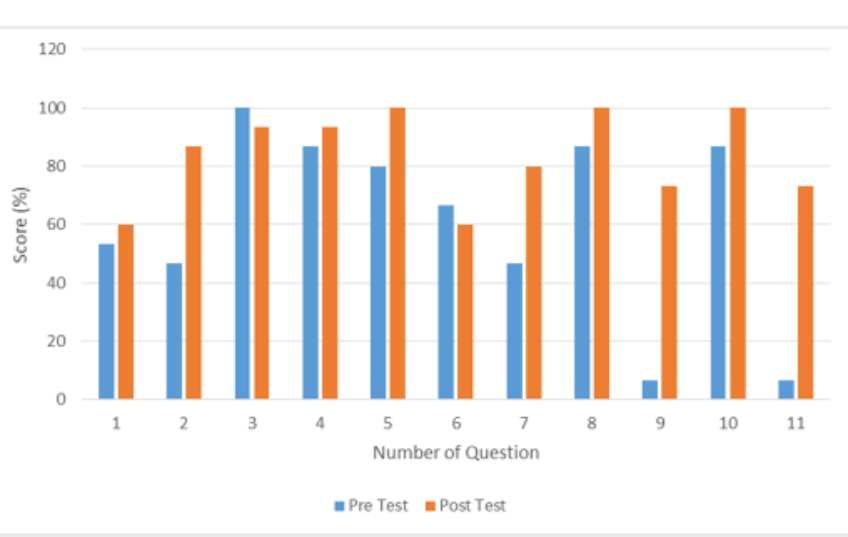

Fig. 12 Score chart of the pretest and posttest question.

\section{Conclusion}

The impacts of teaching the effects of dextrin binder composition on bamboo fiber and dried clove leaves briquettes to high school students have been studied. The results of teaching through instructional video media for students show increased results for understanding biomass briquettes and increasing the amount of binder strengthened the briquettes and more efficient of fuel usage. The results of characterization through testing compressed density, relaxed density, relaxation ratio, percentage of moisture content, percentage of water resistance index, water boiling test, burning rate, specific fuel consumption, and percentage of durability index shows good resistance, density and fuel consumption of briquettes obtained from $60 \%$ binder composition while good briquette on cooking ability was obtained from the binder composition of $20 \%$. Briquettes can be made from bamboo fibers and dried clove leaves using a dextrin binder. Instructional videos can be used as an alternative media to convey the alternative of coals usage in the form of biomass briquette with dextrin binder to senior high school students. The future directions on this paper are varying the composition on the dried clove leaves more than $1: 10$ ratio.

\section{References}

Aisyah, I. S., Saifullah, A., and Satya, T. (2017). Proses desain dan pengujian mesin press hidrolik, Seminar Nasional Teknologi dan Mesin. ISSN : 1517-6042.

Aklis, N. (2018). Karakteristik Pembakaran limbah daun cengkeh sisa proses penyulingan minyak cengkeh melalui sistem co combustion dan briketing, Simposium Nasional RAPI VII, 2018(04), 8-15. 
Brunerova, A., Roubik, H., and Brozek, M. (2018). Bamboo fiber and sugarcane skin as a bio-briquette fuel. Energies, $11(9), 2186$.

Grover, P. D. and Mishra, S. K. (1996). Regional wood energy development programme in Asia Gcp/Ras/154/Net biomass briquetting, food and agriculture organization of the United Nations, Bangkok.

Hamdanillah, N., Harjono, A., and Susilawati, S. (2017). Pengaruh model pembelajaran advance organizer menggunakan video pembelajaran terhadap hasil belajar fisika peserta didik kelas XI, Jurnal Pendidikan Fisika dan Teknologi, 3(2), 119.

Imamah, N. (2012). Peningkatan hasil belajar IPA melalui pembelajaran kooperatif berbasis konstruktivisme dipadukan dengan video animasi materi sistem kehidupan tumbuhan, Jurnal Pendidikan IPA Indonesia, 1(1), 32-36.

Iskandar, T. and Suryanti, G. (2016). Efektivitas bentuk geometri dan berat briket bioarang dari bambu terhadap kualitas penyalaan dan laju pembakaran, Jurnal Teknik Kimia, 10(1), 8-12.

Kale, J., Mula, Y. R., Iskandar, T., and Abrina, S. P. (2019). Optimalisasi proses pembuatan briket arang bambu dengan menggunakan perekat organik. Seminar Nasional Teknologi Industri, Lingkungan dan Infrastruktur (SENTIKUIN), 2, 17.

Kuti, O. A. and Adegoke, C. O. (2008). Comparative performance of composite sawdust briquette with kerosene fuel under domestic cooking conditions. AU Journal of Technology, 12(1), 57-61.

Kuti, O. A. (2009). Performance of composite sawdust briquete fuel in a biomass stove under simulated condition, AU Journal of Technology, 12(4), 284-288.

Maryanti, R., Hufad, A., Sunardi, S., Nandiyanto, A. B. D., and Al-Obaidi, A.S.M. (2020). Understanding covid-19 particle contagion through aerosol droplets for students with special needs. Journal of Engineering Science and Technology, 15(3), 1909-1920.

Mitchual, S. J., Frimpong-mensah, K., and Darkwa, N. A. (2013). Effect of species, particle size and compacting pressure on relaxed density and compressive strength of fuel briquettes, International Journal of Energy and Environmental Engineering, 4(30), 2-7.

Nurhadianty, V., Cahyani, C., Nirwana, W. O. C., Dewi, L. K., Abdillah, G., and Pratama, A. R. (2017). Peningkatan yield minyak daun cengkeh (syzygium aromaticum) dengan fermentasi selulotik menggunakan trichoderma harzianum, Jurnal Rekayasa Bahan Alam dan Energi Berkelanjutan, 1(1), 36-41.
Oladeji, J. (2010). Fuel characterization of briquettes produced from corncob and rice husk resides. Pacific Journal of Science and Technology, 11(1), 101-106.

Onuegbu, T. and Ekpunobi, U. (2011). Comparative studies of ignition time and water boiling test of coal and biomass briquettes blend, International Journal of Recent Research and Applied Studies, 7(2), 153-159.

Pamungkas, A. S., Ihsanudin, Novaliyosi, and Yandari, I. A. V. (2018). Video Pembelajaran berbasis sparkol videoscribe: inovasi pada perkuliahan sejarah matematika, Prima: Jurnal Pendidikan Matematika, 2(2), 127.

Patabang, D. (2012). Karakteristik termal briket arang sekam padi dengan variasi bahan perekat, Jurnal Mekanikal, 3(2), 286-292.

Pradilasari, L., Gani, A., and Khaldun, I. (2019). Pengembangan media pembelajaran berbasis audio visual pada materi koloid untuk meningkatkan motivasi dan hasil belajar siswa SMA, Jurnal Pendidikan Sains Indonesia, 7(1), $9-15$.

Purwanti, B. (2015). Pengembangan media video pembelajaran matematika dengan model assure, Jurnal Kebijakan dan Pengembangan Pendidikan, 3(1), 42-47.

Putra, I. G. L. A. K., Tastra, I. D. K., and Suwatra, I. I. W. (2014). Pengembangan media video pembelajaran dengan model addie pada pembelajaran bahasa inggris di SDN 1 Selat, Jurnal Edutech Universitas Pendidikan Ganesha, 2(10, $1-10$.

Putra, H. H., Mokodompit, M., and Kuntari, A. (2016). Briket dari limbah bambu dengan perekat nasi, Jurnal Teknologi, 6(2), 116-123.

Sanaky, A. H. (2013). Media Pembelajaran InteraktifInovatif, Kaukuba, Yogyakarta.

Singh, R. N. (2004). Equilibrium moisture content of biomass briquettes, Biomass and Bioenergy, 26(3), 251-253.

Suarya, P. (2008). Adsorpsi pengotor minyak daun cengkeh oleh lempung teraktivasi asam, Jurnal Kimia, 2(10, 19-24.

Sulistya, D. A. (2018). Pengembangan quantum teaching berbasis video pembelajaran camtasia pada materi permukaan bumi dan cuaca, Profesi Pendidikan Dasar, 1(2), 169.

Tambaria, T. N. and Serli, B. F. Y. (2019). Kajian analisis proksimat pada briket batubara dan briket biomassa. Jurnal Geosains and Teknologi, 2(2), 77-86.

Thabuot, M., Pagketanang, T., Panyacharoen, K., Mongkut, 
P., and Wongwicha, P. (2015). Effect of applied pressure and binder proportion on the fuel properties of holey biobriquettes, Energy Procedia, 79, 890-895.

Tumuluru, J. S., Tabil, L. G., Song, Y., Iroba, K. L., and Meda, V. (2015). Impact of process conditions on the density and durability of wheat, oat, canola, and barlet straw briquettes, Bioenergy Research, 8(1), 288-401.

Widodo, A. A. (2016). Pengaruh tekanan terhadap karakteristik briket bioarang dari sampah kebun campuran dan kulit kacang tanah dengan tambahan minyak jelantah, Universitas Islam Indonesia, Yogyakarta.

Yahaya, D. B. and Ibrahim, T. G. (2012). Development of rice husk briquettes for use as fuel, Research Journal in Engineering and Applied Sciences, 1(2), 130-133.

Yaman, S., Sahan, M., Haykiri-Acma, H., Sesen, K., and Kucukbayrak, S. (2001). Fuel briquettes from biomasslignite blends. Fuel Processing Technology, 72(1), 1-8.

Yulinar, R. D. (2020). Pengaruh campuran arang kayu terhadap karakteristik briket limbah daun cengkeh, Universitas Negeri Semarang, Semarang.

Zhang, G., Sun, Y., and Xu, Y. (2018). Review of briquette binders and briquetting mechanism, Renewable and Sustainable Energy Reviews, 82(2018), 477-487. 